\title{
FIXING THE “UNDUE HARDSHIP” HARDSHIP: SOLUTIONS FOR THE PROBLEM OF DISCHARGING EDUCATIONAL LOANS THROUGH BANKRUPTCY
}

\author{
Adam J. Williams ${ }^{*}$
}

Imagine John Smith, soon to be John Smith, Esquire. He has completed his last round of finals and is anxiously awaiting graduation from law school. In the time between finals and graduation, when many third-year law students are taking a brief mental vacation before bar exam preparation gets into full swing, John thinks he has found the ultimate loophole. John files a bankruptcy petition, which shows his non-existent current income, minimal assets, and education loans totaling over $\$ 100,000$. Given John's apparent insolvency, the court discharges his student loans so that John can have a fresh start and attempt to get back on his feet. John is pleased because he has a great job lined up for after graduation, and getting rid of this debt will make his life better. Luckily for the taxpayers who would then be responsible for John's federally guaranteed student loans, Congress essentially eliminated such a possibility decades ago, and college students across the country can rest easy knowing that their loans will be fully intact upon graduation.

The first part of this paper gives a brief summary of the history of bankruptcy. Part II discusses the history of student loans in the United States. Part III gives an overview of the standards and tests for discharging student loans through bankruptcy, including the Johnson, Bryant, Brunner, and Totality of the Circumstances Tests. Finally, Part IV contains suggestions for making a uniform law, as well as for making the repayment of loans more likely by shifting the responsibility for guaranteeing repayment from the government to the schools.

\section{A History of BAnKRuptCy Laws}

It is a common understanding that as long as we have had debt, we have had some form of bankruptcy. Even the Holy Bible refers to forgiving the debts of others after seven years. ${ }^{1}$ Once upon a time, a creditor could resort to

* J.D./M.B.A. Candidate, 2008, University of Pittsburgh.

1. Deuteronomy 15:1-11 ("At the end of every seven years, you shall grant a release. And this is the manner of the release: every creditor shall release what he has lent his neighbor, he shall not exact it of 
several possible means in order to collect what was owed to him. Of course, not everyone in those times listened to the commands of the Bible, and in some situations, debtors were sold as slaves to repay their debts. ${ }^{2}$ In ancient Rome, creditors could, after a period of default, force debtors into servitude and choose to either sell them or kill them. ${ }^{3}$ The term bankruptcy originates in medieval Italy where a merchant who could not pay his debts would be subject to the destruction of his trading bench, resulting in a "broken bench," or "banca rotta."

Since its early beginnings, debtor and creditor law has evolved significantly. England's first bankruptcy law, "An Act Against Such Persons As To Make Bankrupts," was enacted in 1542 and lacked any provisions granting discharge to the debtor. ${ }^{5}$ The law was primarily used as a collection device for creditors and treated debtors as quasi-criminals. ${ }^{6}$ Additionally, the law only applied to traders because there was an assumption that non-traders lacked the wherewithal to commit the acts associated with being a bankrupt. ${ }^{7}$ In fact, at this time, most people viewed credit as evil, and delay of payment was seen as dishonest. ${ }^{8}$

Over 160 years later, in 1705, the English law adopted the idea of discharge. ${ }^{9}$ By the mid $1700 \mathrm{~s}$, the view of a debtor as evil had begun to evaporate as the Industrial Revolution spread across the world. ${ }^{10}$ Of course, some of the early provisions remained intact, and laws that favored creditors, while threatening death to fraudulent debtors, set the backdrop for bankruptcy laws at the time of the ratification of the United States Constitution. ${ }^{11}$

In the United States, the Constitution gives Congress the power to establish bankruptcy laws. ${ }^{12}$ The reasoning behind giving the federal government the power to create bankruptcy laws was explained by James

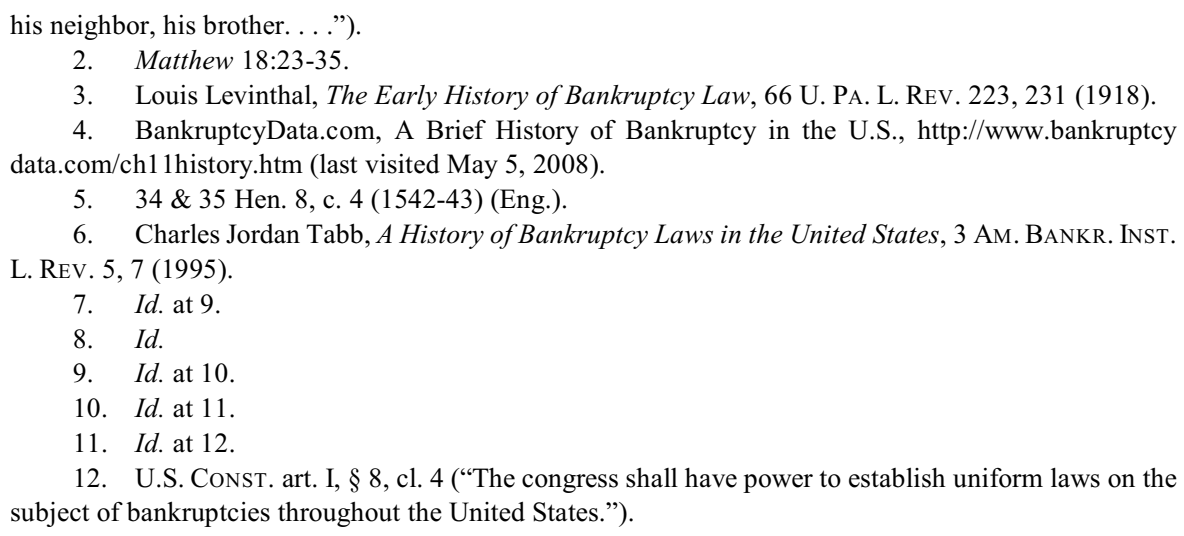


Madison: "The power of establishing uniform laws of bankruptcy is so intimately connected with the regulation of commerce, and will prevent so many frauds where the parties or their property may lie or be removed into different states that the expediency of it seems not likely to be drawn into question." 13

Yet, it was more than 100 years after the ratification of the Constitution that Congress passed the first permanent bankruptcy law. ${ }^{14}$ This law, The Bankruptcy Act of $1898,{ }^{15}$ contained significant pro-debtor provisions, which was a change of direction from the early English laws, which were primarily a remedy for creditors. ${ }^{16}$ Of course, there were still several provisions that favored creditors, which facilitated the equitable and efficient distribution of the debtor's property. ${ }^{17}$ In fact, bankruptcy at this time was still an involuntary proceeding from the debtor's perspective. ${ }^{18}$

Congress passed several amendments to the Bankruptcy Act of 1898 over the years, ${ }^{19}$ but there was no significant reform of the Act for almost 100 years. In 1970, Congress created the Commission on the Bankruptcy Laws of the United States (The Commission) in order to study and report on the existing law. ${ }^{20}$ The Commission published its report in 1973, which became the basis of the Bankruptcy Reform Act of $1978 .^{21}$

Among many noteworthy provisions, the Bankruptcy Reform Act of 1978 contained an exception to discharge for student loans. ${ }^{22}$ This was the result of a compromise between the House bill, which contained no such provision, ${ }^{23}$ and the Senate draft of the bill, which adopted the exact language that the Commission suggested. ${ }^{24}$ The Commission reasoned that such a provision was necessary because:

Examples of the abuse of the discharge in the case of educational loans have come to the Commission's attention. Some individuals have financed their education and

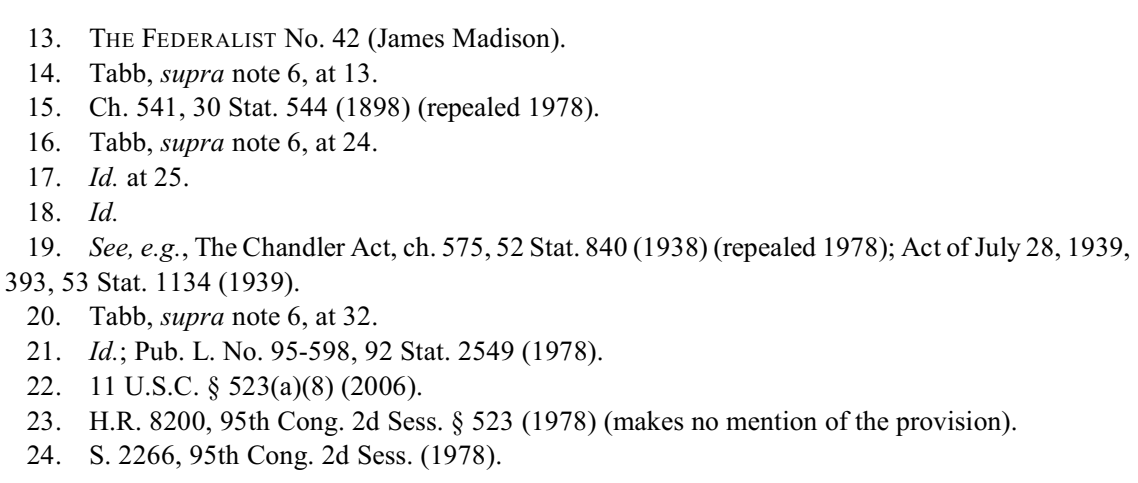


upon graduation have filed petitions under the Bankruptcy Act and obtained a discharge without any attempt to repay the educational loan and without the presence of any extenuating circumstance, such as illness. The Commission is of the opinion that not only is this reprehensible but that it poses a threat to the continuance of educational loan programs. ${ }^{25}$

The U.S. Commissioner of Education reported that between 1972 and 1975, the default rate of Federally Guaranteed Student Loans increased from 4.3\% to $18.5 \% .{ }^{26}$ This was a motivating factor in creating an exception to discharge for student loans.

For a more comprehensive history of bankruptcy laws in the United States, see The History of Bankruptcy Laws in the United States by Charles Jordan Tabb. ${ }^{27}$

\section{History of Federally Guaranteed Student Loans}

Federal aid for colleges and universities is a fairly recent creation in the history of the United States, with its inception occurring in the 1920s and $30 \mathrm{~s} .{ }^{28}$ As the demand for higher education grew around the time of World War I, tuition rates rose accordingly. ${ }^{29}$ Seeing the benefits that higher education provides to the citizens of the nation, Congress passed the Servicemen's Readjustment Act of 1944, commonly known as the GI Bill, ${ }^{30}$ which was a form of deferred compensation for soldiers who chose to enter school. ${ }^{31}$ The GI Bill was the start of federal funding for higher education in the United States; however, it was lacking in several respects, notably in its availability to the general public.

The United States Government established the first widely available federal aid program during the Cold War in response to the United States' concern over the educational and scientific advancements of the Russians. ${ }^{32}$

25. H.R. Doc. No. 93-137 (1973).

26. Arthur M. Hauptman, Student Loan Defaults: Toward a Better Understanding of the Problem, in Student Loans: Problems And Policy Alternatives 125, 131 (Lois D. Rice ed., 1977).

27. Tabb, supra note 6 .

28. Robert B. Archibald, Redesigning the Financial Aid System: Why Colleges and Universities Should Switch Roles with the Federal Government 26-27 (The Johns Hopkins University Press 2002).

29. Id. at 28 .

30. 58. Stat. 287 (1944).

31. ARCHIBALD, supra note 28 , at 28 .

32. Sheila Dow-Ford, History and Goals of the Student Loan Program, in Student Loan Program, A Journey Through the World of Educational Lending, Collection, and Litigation 3 (Pennsylvania Bar Institute 2003). 
This program was named, appropriately, the National Defense Student Loan (NDSL) Program. ${ }^{33}$

Even though the NDSL was the first widely available federal student aid program, it still had its limitations on availability. In 1965, Congress enacted the Higher Education Act (HEA) to provide financial assistance to low income students and their families. ${ }^{34}$ A significant addition made by the HEA was the Guaranteed Student Loan (GSL) Program. The GSL program is comparable to today's Stafford Loan Program. ${ }^{35}$ The Government guaranteed payment of the loans in the event that the borrower defaulted and subsidized the interest payments while the student was in school. ${ }^{36} \mathrm{With}$ college becoming more affordable because of these programs, the demand for higher education continued to grow. This program, and others like it, resulted in the federal government guaranteeing over $\$ 2.6$ billion in aid for 2.3 million students in the $1975-76$ academic year. ${ }^{37}$

\section{History and Development of the “Undue Hardship” Standard}

The issue of whether student loans should be dischargeable in bankruptcy was not a concern for the government until the 1970s. The initial concept for non-dischargeability of student loans was a result of a report by a Congressional Commission on Bankruptcy Laws. ${ }^{38}$ Rumors were swirling throughout the country, largely as a result of media reports, that one out of every five students defaulted on his or her student loans. ${ }^{39}$ These rumors motivated Congress to act because the Federal Government guaranteed a majority of student loans at this time, and citizens were concerned that their tax dollars were being spent to pay for someone else's education. ${ }^{40}$ In response, the Commission proposed legislation that would make student loans non-dischargeable if the loans became due more than five years before the filing of the bankruptcy or if failure to discharge the debt would result in an

33. Id.

34. Id.

35. Id.

36. Id.

37. Bruce D. Johnstone, Student Loans: Problems and Policy Alternatives, in Student LoAns: Problems and Policy Alternatives 16, 16 (Lois D. Rice ed., 1977).

38. Lohman v. Conn. Student Loan Fund., 79 B.R. 576, 580 (Bankr. D. Vt. 1987).

39. See Thad Collins, Forging Middle Ground: Revision of Student Loan Debts in Bankruptcy as an Impetus to Amend 11 U.S.C. $\S 523(a)(8), 75$ IowA L. REV. 733, 739-40 (1990).

40. Johnstone, supra note 37. 
"undue hardship" to the debtor. ${ }^{41}$ The Senate adopted the Commission's language verbatim, and it eventually made its way into Section 523 of the final version of the Bankruptcy Reform Act of 1978. Although it took Congress five years from the time of the report to enact the Bankruptcy Reform Act of $1978,{ }^{42}$ it was the first major bankruptcy reform since the original Bankruptcy Act of 1898 .

There is very little legislative history behind the meaning of "undue hardship," as Congress largely left it up to the courts. ${ }^{43}$ Courts have generally held that the use of the term "undue" is an indication "that Congress viewed garden-variety hardship as an insufficient excuse for a discharge of student loans, but the statute otherwise gives no hint of the phrase's intended meaning." ${ }^{44}$

Since the 1978 Bankruptcy Act, few amendments have been made to Section 523(a)(8). Notably, in 1994, the five-year limitation was expanded to seven years. ${ }^{45}$ Since section 523(a)(8) was originally created to prevent abuse of federal student loans, an expansion from five to seven years was seen as an additional way to prevent abuse. ${ }^{46}$ However, amendments to the bankruptcy code in 1998 completely eliminated the provision for dischargeability of student loans if they became due more than seven years from the filing of the bankruptcy and if the only way to have a student loan discharged is to prove undue hardship. ${ }^{47}$ In a way, this shows Congress's intent to shift the focus primarily onto financial matters and not other factors.

The Bankruptcy Abuse Prevention and Consumer Protection Act of 2005 (BAPCA) was the most significant change since the 1978 Act, ${ }^{48}$ and it made another alteration to section 523. The exception to discharge was broadened to include any education loans from for-profit lenders if the loans were qualified education loans as defined by $\S 221(\mathrm{~d})(1)$ of the Internal Revenue Code. ${ }^{49}$ The most recent version of the law now treats loans from for-profit lenders the same way that loans from the government or non-profit institutions

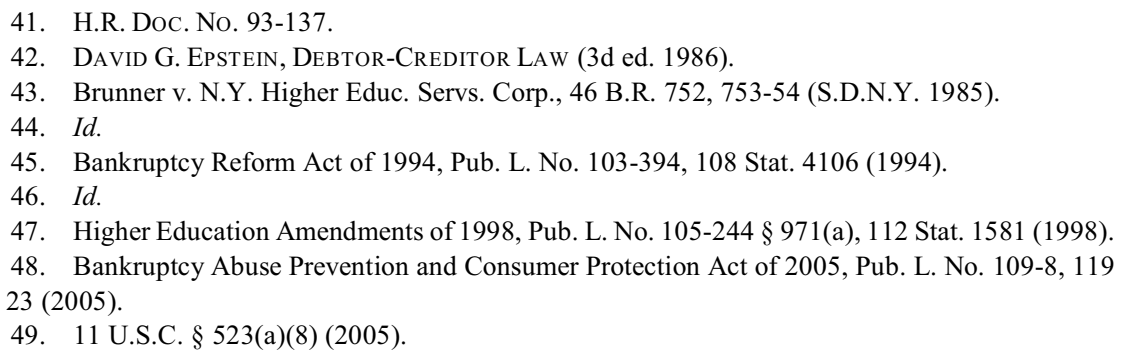


were treated in the past. ${ }^{50}$ The legislature's developments have been muddled as the courts have struggled to develop a uniform standard for discharge.

\section{A. The Johnson Approach}

The earliest test to determine "undue hardship" was created by the United States Bankruptcy Court for the Eastern District of Pennsylvania in Pennsylvania Higher Education Assistance Agency v. Johnson (In re Johnson). ${ }^{51}$ After previous courts had attempted, to no avail, to form a test for undue hardship based on dictionary definitions, the Johnson court designed a three-part test. ${ }^{52}$ The first test, which is considered the "mechanical test," compares a debtor's current and potential income over the entire repayment period with the debtor's expenses to determine whether the debtor is able to make payments on the student loans while maintaining a minimum standard of living. ${ }^{53}$ The court considered many factors in analyzing the debtor's current and future income potential, including the following: earned income, wages and/or salaries earned, sex, ability to obtain and retain employment, current employment status, employment record, skills and education, health, access to transportation, and dependents. ${ }^{54}$ In looking at a debtor's expenses, the court considered monthly expenses for a similarly situated hypothetical debtor, as well as any "extraordinary expenses" that might be specific to the particular debtor. ${ }^{55}$ According to Johnson, factors to consider in determining reasonable expenses for a similarly situated hypothetical debtor include geographic location, marital status, number of dependents, and whether any necessities are available in like kind or at reduced cost. ${ }^{56}$ Extraordinary expenses would include such things as medical expenses that are nondiscretionary. ${ }^{57}$

The second test in the Johnson analysis is a good faith test. ${ }^{58}$ In order to satisfy this test, the debtor must prove that he or she made a bona fide attempt to repay the loan, which would include efforts to maximize income and reduce

50. $I d$.

51. In re Johnson, No. 77-2033TT, 1979 U.S. Dist. LEXIS 11428 (Bankr. E.D. Pa. June 27, 1979).

52. $I d$.

53. Id. at $* 22-36$.

54. Id. at *24-31

55. Id. at $* 31$.

56. $I d$.

57. Id. at $* 32-33$.

58. Id. at $* 41$. 
expenses. ${ }^{59}$ The good faith test ensures that a debtor was put into the situation because of circumstances beyond his or her control and has made reasonable efforts to escape the situation. ${ }^{60}$ If the court finds that the debtor was negligent, the court must also determine whether the absence of such negligence would have led to a higher income or lower expenses for the debtor. $^{61}$

A policy test is the third and final part of the Johnson undue hardship test. The policy test could create a sufficient reason to grant discharge even if the debtor fails the mechanical test or the good faith test. ${ }^{62}$ In considering whether a debtor satisfies the policy test, a court will compare the amount and percentage of student loans to total indebtedness to determine whether the dominant purpose of the bankruptcy is to discharge student loans, or financially benefit the debtor. ${ }^{63}$

\section{B. The Bryant Test}

Two other tests were developed around the same time in the late 1980s. Shortly before the Second Circuit formally adopted the Brunner Test, the United States Bankruptcy Court for the Eastern District of Pennsylvania developed a different test to determine whether an undue hardship would be imposed on the debtor. ${ }^{64}$ In Bryant, the court held that

[U]ndue hardship exists (1) where the debtor has net income which is not substantially greater than the federal poverty guidelines, because a debtor so living perforce is unable to maintain a minimal standard of living and make payments on student loans; or (2) where the debtor has income substantially above the poverty guidelines, but there is a presence of 'unique' or 'extraordinary' circumstances which render it unlikely that the debtor will be able to repay his or her student loan obligations. $^{65}$

Thus, the federal poverty guidelines became, by far, the most important factor to consider, which provided very little flexibility.

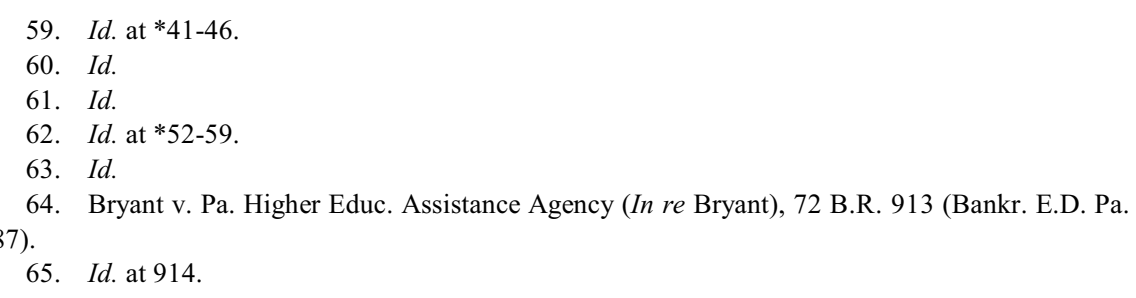




\section{The Brunner Test}

Nearly a decade after the United States District Court for the Eastern District of Pennsylvania created the Johnson Test, the Second Circuit officially adopted a different test to determine whether an undue hardship would arise. ${ }^{66}$ The three-part Brunner Test was created in the Southern District of New York in 1985. ${ }^{67}$ In order to prove that the student loans would impose an undue hardship if not discharged, the debtor must prove: (1) that the debtor cannot, based on current income and expenses, maintain a "minimal" standard of living for himself or herself and his or her dependents if forced to repay the loans; (2) that this state of affairs is likely to persist for a significant portion of the repayment period of the student loan; and (3) that the debtor has made good faith efforts to repay the loans. ${ }^{68}$

In analyzing a debtor's ability to pay under the Brunner Test, courts have looked at the past income of the debtor, including the average and highest amount, to get an indication of what the debtor's future income will probably be. ${ }^{69}$ When considering expenses, courts will look to the necessity of the expenses to determine if the amounts are too high or if the amounts could be eliminated entirely to ensure that a debtor is not living beyond a normal, minimal standard of living and claiming a hardship. ${ }^{70}$ Some courts have held that something as important as transportation can be an extravagant expense if it is abused. ${ }^{71}$

In analyzing the Brunner Test, some commentators have argued that courts are being too strict when they use a poverty level test like the one in Bryant. $^{72}$ However, the court need not strictly scrutinize the debtor's budget. ${ }^{73}$ Courts should examine income and expenses and consider the particular circumstances of the debtor (including needs for care, food, shelter, clothing, transportation, medical treatment, and a small source of recreation) without

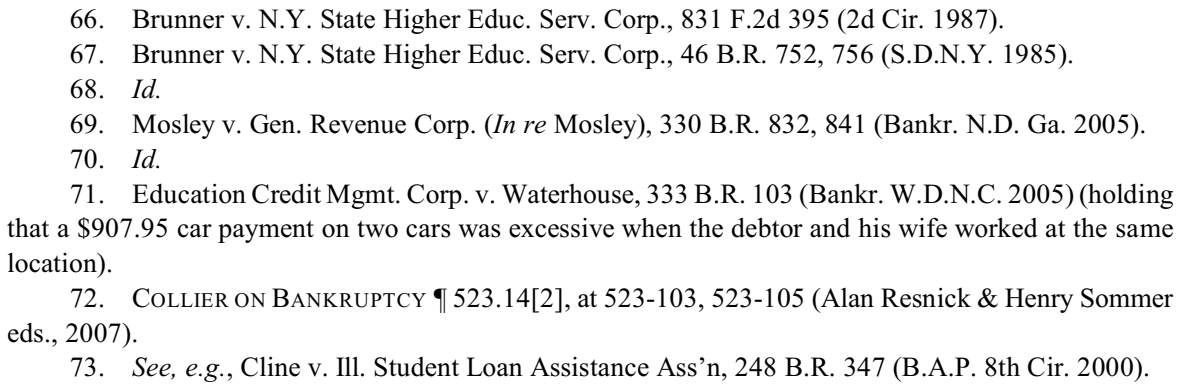


going through his or her budget dollar-by-dollar. ${ }^{74}$ This proposed analysis is based on the fact that even if a debtor is living at or slightly above the poverty level, he or she might still be unable to maintain a minimal standard of living.

To satisfy the second prong of the Brunner Test, the debtor must prove by a preponderance of the evidence that the situation is "likely" to continue for a significant portion of the repayment period. ${ }^{75}$ Courts consider factors such as whether a teacher is taking a job during the summer to earn additional income ${ }^{76}$ whether a debtor left a higher paying job for a lower paying job due to lifestyle choices ${ }^{77}$ or whether a present disability will prevent the debtor from earning more income in the future. ${ }^{78}$ Additionally, if the debtor has minor children who will reach an age of independence or majority in the near future, courts have held that the debtor's financial situation is not likely to persist. ${ }^{79}$ These are considered situations where the debtor should reasonably be able to increase income or decrease expenses.

The final part of the Brunner Test is a good faith inquiry. In this step, the court examines whether the debtor's financial situation was caused by the debtor's own willfulness or negligence, or by circumstances beyond the debtor's control. ${ }^{80}$ One can even satisfy this test if a payment was never made on the student loans, as long as the lack of payment was for reasons beyond the debtor's control. ${ }^{81}$ Some creditors have argued that the good faith test is not met if the debtor has not applied for an income-contingent repayment plan (ICRP). ${ }^{82}$

ICRPs require a minimal payment when the debtor's income exceeds the federal poverty guidelines. However, there is a strong presumption that an income slightly above the poverty level would not afford the debtor a minimal standard of living. ${ }^{83}$ Additionally, under the ICRPs, interest accrues throughout the repayment period, which could be as long as twenty-five years, making the amount due at the end of the term greater than the amount due at the beginning, even if every payment is made. This leads to a situation where

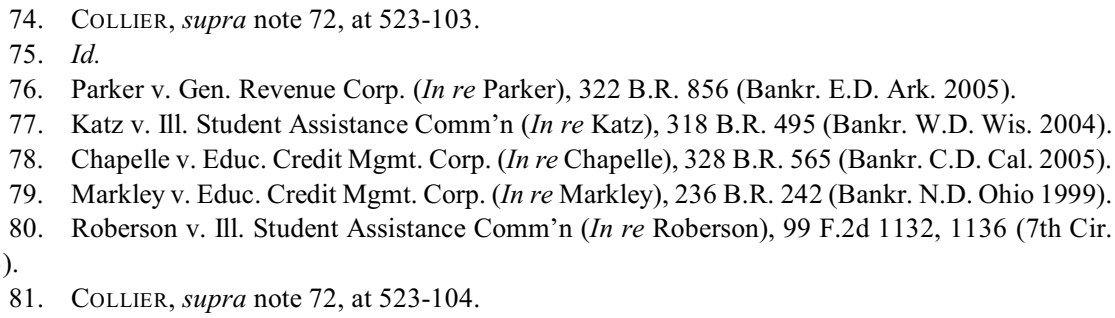


debt is forgiven at the end of the period, imposing a huge tax burden on the debtor ${ }^{84}$ Although debt that is forgiven through bankruptcy proceedings is typically excluded from one's taxable income, ${ }^{85}$ the debt that is forgiven after an ICRP repayment period ends does not fall under an income exception, and the debtor would be taxed on his or her forgiveness of debt income. Other commentators say that the availability of an ICRP should only be one factor to which courts look to determine whether an undue hardship is inevitable, and should not be dispositive. Whether a debtor has attempted to take advantage of an ICRP is also considered in analyzing the first two prongs of the Brunner Test. ${ }^{86}$

In the end, the ultimate determination comes down to whether a judge feels that a debtor can maintain a minimal standard of living while making payments on the loan. Nevertheless, this gives judges too much discretion in determining exactly what is a "minimal" standard of living, and courts applying the Brunner Test have not come to a consensus as to what factors should be considered. Additionally, judges must also determine how much sacrifice a debtor should make when trying to repay loans from which he or she, presumptively, obtained little or no benefit. ${ }^{87}$

\section{The Totality of the Circumstances Test}

In addition to the three aforementioned tests, a number of courts have expressed a preference for a more flexible test that would look at a variety of factors in determining undue hardship, but such a test would still necessarily require those courts' subjective consideration of what it is that constitutes "undue hardship." A totality of the circumstances analysis will consider many of the same facts as the Brunner Test, and will also often result in a similar outcome. ${ }^{89}$ Courts have considered a number of additional factors in

84. Id.

85. 26 U.S.C. $\S 108(a)(1)(A)(2000)$.

86. Terrence L. Michael \& Janie M. Phelps, “Judges?! —We Don't Need No Stinking Judges!!!”: The Discharge of Student Loans in Bankruptcy Cases and the Income Contingent Repayment Plan, 38 Tex. Tech L. Rev. 73, 89 (2005).

87. COLLIER, supra note 72, at 523-105.

88. Andrews v. S.D. Student Loan Assistance Corp. (In re Andrews), 661 F.2d 702 (8th Cir. 1981); Law v. Educ. Res. Inst. (In re Law), 159 B.R. 287, 292-93 (Bankr. D. S.D. 1993); Moorman v. Ky. Higher Educ. Assistance Auth. (In re Moorman), 44 B.R. 135, 137-38 (Bankr. W.D. Ky. 1984); D’Ettore v. Devry Inst. of Tech. (In re D’Ettore), 106 B.R. 715, 718 (Bankr. M.D. Fla. 1989).

89. Andreson v. Neb. Student Loan Program, Inc. (In re Andreson), 232 B.R. 127, 140-41 (BR Appellate Panel of the 8th Cir. 1999). 
their case-by-case analysis that make the totality of the circumstances test more flexible and often more beneficial to the debtor than the other three tests. ${ }^{90}$

\section{E. Current Debate Concerning Complete Repeal of $\$ 523(a)(8)$}

Besides the debate about which judicial test to apply, some commentators, as well as the National Bankruptcy Review Commission, have argued that $\S 523(\mathrm{a})(8)$ should be repealed in its entirety. ${ }^{91}$ This argument is based on the belief that the debtors who are most in need of a discharge (i.e., those with the lowest incomes) are the least able to litigate the student loan issue, which makes obtaining a "fresh start" nearly impossible. ${ }^{92}$ Additionally, the Commission explains that the discharge of bankruptcy can be applied to debts incurred to buy a car, a vacation, or a pizza, but it cannot be applied to debts incurred to obtain an education, and this is not a policy that the government should promote. ${ }^{93}$ Furthermore, the Commission argues that the government, in this situation, should not have debts that are considered to be as high a priority as debts owed for fraud, taxes, and drunk driving accidents. ${ }^{94}$ The Commission also relies on reports of proprietary schools and bankers exploiting students. ${ }^{95}$

Probably the strongest argument in favor of repealing $\S 523(\mathrm{a})(8)$ is based on the fact that the alleged abuse of discharging loans immediately upon graduation turned out to be a much smaller problem than originally thought. ${ }^{96}$ The perceived abuse from stories in the press was a significant factor leading to the drafting of $\S 523(\mathrm{a})(8)$, but the reality of the situation turned out not to be so grim. ${ }^{97}$

Even though there are strong arguments in favor of a complete repeal of the undue hardship exception, it would lead to two related problems. First, even though the problem of perceived abuse was small, it was still a problem that could potentially cost the government a significant amount of money, especially given the fact that the government provided about $\$ 78$ billion in

90. See, e.g., id. at 141 (considering extraordinary expenses of treatment for minor daughter's medical problems).

91. Nat'l Bankr. Review Comm'n, Bankruptcy: The Next Twenty Years 1.4 .5 (1997).

92. Id.

93. Id.

94. Id.

95. $I d$.

96. Id.

97. $I d$. 
student loans during the 2005-2006 school year. ${ }^{98}$ Second, the amount of abuse would only increase if the opportunity for abuse was more widely available. Reducing the restrictions on discharging educational loans in bankruptcy is a step in the right direction, but complete repeal of $\S 523(\mathrm{a})(8)$ is a step that goes too far. Additionally, complete repeal, and an increased likelihood of discharge, creates a reduced incentive to lend and higher risks for lenders, which leads to higher interest rates. Since student loans are not secured like a mortgage, there is an additional risk to lenders and to the government alike.

\section{F. Current Debate Concerning Partial Discharge of Student Loans}

Another debate regarding student loans in discharge concerns the issue of "partial discharge." The first case to create such a solution was In re MacPherson. ${ }^{99}$ MacPherson, under the 1965 Higher Education Act, and In re Littell, ${ }^{100}$ under the Bankruptcy Reform Act of 1978, are both cases where the court decided that the proper remedy would be to discharge only that portion of the student's debt that would cause an undue hardship, and to leave the rest of the debt intact. ${ }^{101}$ The courts held that $\S 523(\mathrm{a})(8)$ 's silence on the issue of partial discharge left open the possibility for bankruptcy courts to use their equitable powers to discharge a portion of the debt. ${ }^{102}$ Some courts have followed the Littell standard of discharging an arbitrary amount of the student loans, ${ }^{103}$ while others have discharged the interest and required payback of only the principal amount. ${ }^{104}$ Still other courts have chosen to discharge some debts under distinct loans, while exempting from discharge other student debts from other loans.

The policy reason for partially discharging student loans, using any of the above alternatives, involves a balance of overall fairness to the debtor and creditor. ${ }^{105}$ Partial discharge results in the debtor obtaining some relief from the student loans to make a "fresh start" and makes repayment more likely.

98. Student Aid on the Web, http://studentaid.ed.gov/PORTALSWebApp/students/english/aboutus .jsp (last visited June 6, 2008).

99. For a discussion of MacPherson, see Collins, supra note 39, at 749-50 (1990).

100. Littell v. State of Or. (In re Littell), 6 Bankr. 85 (Bankr. E.D. Or. 1980).

101. Collins, supra note 39 , at $749-50$.

102. $I d$.

103. See In re Luna, 54 B.R. 637, 638 (Bankr. S.D. Fla. 1984); Hagen v. Avangel Coll., Inc. (In re Hagen), 36 B.R. 578, 579 (Bankr. M.D. Fla. 1983).

104. See Collins, supra note 39 , at 749-50.

105. Id. at 753-54. 
Partial discharge also results in the creditor receiving at least partial payment for the loan, so the situation does not turn out to be a significant loss for lenders. ${ }^{106}$

Partial discharge is not, however, the best solution for solving the problems associated with discharging student loans through bankruptcy. There is no direct authority in $\S 523(\mathrm{a})(8)$ that gives courts the power of partial discharge. Additionally, partial discharge gives courts too much flexibility. It allows judges too much leniency in imposing their own values and perceptions on the debtors and in deciding which lenders should actually be paid. ${ }^{107}$ Partial discharge also makes an outcome even less predictable for a debtor and could increase litigation costs associated with working out the minutest details in a debtor's budget.

\section{Proposed Uniform “Undue Hardship” Standard}

The first step that should be taken in remedying the current situation involves Congress's adoption of a uniform standard for "undue hardship," since the Constitution requires uniform bankruptcy laws. ${ }^{108}$ Congress should adopt a test that combines the strengths of the Bryant, Johnson, Brunner, and Totality of the Circumstances Tests. Courts should apply a test that only looks at the current and potential income of the debtor as compared to his or her current and expected future expenses. Regardless of a debtor's intent, if the debtor is unable to make payments on the loan and would be unable to make payments for the life of the loan while maintaining a minimal standard of living, the loan should be discharged. A good faith approach like the one in Johnson and Brunner should also be applied to ensure that the debtor is making efforts to maximize income while reducing expenses. A court should look at the reasonableness of the debtor's expenses and determine whether the debtor is spending frivolously. This approach would also consider exceptional circumstances such as medical conditions, marital status, and dependents, all of which would influence the amount of expenses a debtor should reasonably have. The current good faith standard contains too many pitfalls for debtors, especially considering the fact that many of the default statistics upon which Congress relied have been questioned. ${ }^{109}$ Additionally, the primary purpose of Johnson's policy test misses the point of an "undue hardship" analysis. The

106. Id. at 754 .

107. Id. at 761 .

108. U.S. Const. art. I, $\S 8$, cl. 4.

109. ARChiBALD, supra note 28. 
debtor's intent or purpose in filing bankruptcy has no affect on whether forcing repayment will cause an undue hardship.

Additionally, Congress should codify exactly what constitutes a "minimal standard of living," since a test that adheres strictly to the poverty level test does not take into consideration the fact that even if a debtor has an income above poverty level, he or she may not be able to maintain a minimal standard of living. Some may argue that poverty levels are already set at such a level, but in fact poverty level determinations are made not just with respect to a set standard of living, but also with regard to what is required to bring the general population up to that level. The limited resources that the government has to make distributions to bring people up to this level comprise one ingredient in the compromise made in determining poverty levels.

A test that considers only a debtor's good faith ability to pay would be much less complicated for courts to apply than the Johnson Test. It also forces the courts, lenders, and the government to face the facts: regardless of whether discharging a debt is in line with the policy behind the law, if the debtor is unable to pay, the debt will not be paid. This means the debt will be treated similar to other unsecured debts. It is an unfortunate circumstance that some debtors will act willfully or negligently and be put into a position where they cannot afford to make payments on their educational loans. Irresponsible behavior can lead to circumstances beyond a debtor's control. Sometimes, nothing can be done aside from discharging their debts through bankruptcy and giving them a "fresh start."

Congress must also take additional steps besides codifying a uniform standard for undue hardship. Like the Johnson Test, this standard should be one which not only considers the current and potential income and expenses of the debtor, but which also ensures that the income and expenses are reasonable.

\section{Shift the Responsibility fRom TAXPayers to Academic Institutions}

Congress must also shift some of the responsibility for collecting on student loans. History has shown that ambivalence on the part of the government has led to a situation where much of the risk of default on student loans is shifted to the government and, consequently, onto taxpayers. ${ }^{110}$ Currently, over 3,000 schools are considered "qualified lenders" under federal 
loan programs with little consideration given to the qualifications for eligibility to the programs. ${ }^{111}$ This has created the somewhat undesirable situation in which schools can loan money to students and be guaranteed repayment by the government, allowing them to increase tuition at a more rapid pace. They receive the benefit of full payment while the rest of the population pays the costs of default. For schools, therefore, there is no real risk of default. It has also created a situation where students treat federal education loans differently than "real loans," because they know the education loans will be paid off. Consequently, students are given little incentive to prepare for managing debt in the real world, where students will have to make payments on "real loans." 112 Additional problems for lenders are their inability to repossess human capital the way that they can repossess property and the impracticality of requiring students, who generally own very little, to provide collateral before receiving a loan. ${ }^{13}$

Most of the other dischargeability exceptions in 11 U.S.C. $\S 523$ have methods, such as attaching tax refunds or garnishing wages, to ensure the payment of debts. Consequently, we have seen a decrease in the amount that these types of debts are discharged in bankruptcy each year. Along these lines, Congress should tie funding for educational institutions to the default rates of their graduates to create an incentive for schools to better prepare their students to pay off the loans. Schools and lenders would then make more of an effort to teach financial management to their students and probably convince some students to pursue courses of study that have a better chance of offering a return on investment. ${ }^{114}$

People grow up understanding that failure to pay taxes has unavoidable consequences. Similarly, people know that there will be ramifications when they cause a drunk driving accident. These lessons are taught throughout a person's lifetime by parents and schools. Similar lessons should be taught on financial management, but the only way this will happen is if there is an incentive to do so. A correlation between government funding and repayment rate is such an incentive.

111. Id. at 23 .

112. Id.

113. Hauptman, supra note 26, at 128.

114. Id. at 127. 